\title{
Effect of Social Capital on Productivity of Rice Farms in Kwara State, Nigeria
}

\author{
Olubunmi Abayomi Omotesho, Abraham Falola* and Adeshola Temitope Oshe
}

Department of Agricultural Economics and Farm Management, Faculty of Agriculture, University of llorin, P. M. B 1515, llorin, Kwara State, Nigeria

\begin{tabular}{ll}
\hline \multicolumn{1}{c}{ Abstract } & Article Information \\
\hline This study examines the role of social capital in rice production in Kwara State, Nigeria. & Article History: \\
Primary data obtained from 90 rice farming households through a combination of purpose & Received $: 13-01-2015$ \\
and random sampling techniques were used for the study. The data collected were analysed & Revised $: 19-03-2015$ \\
with descriptive statistics, total factor productivity index, analysis of variance (ANOVA) and & Accepted : 23-03-2015 \\
\cline { 2 - 2 } probit regression. The study revealed that the farmers participated in religious, cooperative, & Keywords: \\
mutual support and farmers groups. Farmers' participation in the social groups is & Social Groups \\
significantly influenced by age $(P<0.05)$, education $(P<0.05)$, opinion about influence of & Participation \\
membership of social group on one's religious fervency $(P<0.01)$ and access to extension & Factors \\
services $(P<0.01)$. Further, the study revealed a positive impact of social capital on farm & Productivity \\
\cline { 2 - 2 } productivity of rice in the study area. It is therefore recommended that government should & *Corresponding Author: \\
formulate relevant policies for better coordination of social groups so that farmers would be & Abraham Falola \\
encouraged to participate in them. & E-mail: \\
falolaabraham@yahoo.com & falola.a@unilorin.edu.ng \\
\hline
\end{tabular}

\section{INTRODUCTION}

With a population of about $167,912,561$ inhabitants (NPC, 2012), Nigeria is Africa's most populous country constituting about half of West Africa's population (World Bank, 2013). Agriculture is the largest sector of the country's economy, accounting for about $42 \%$ of gross domestic product (GDP) and providing employment to about $60-70 \%$ of the labour force (FSDH, 2013; IFAD, 2012). Notwithstanding, achieving self-sufficiency in agricultural production to feed the increasing population of the country remains a challenge. According to FMARD (2012), Nigeria's food imports are growing at an unsustainable rate of $11 \%$ per annum. One major crop of concern in this regards is 'rice' in which Nigeria still has a supply-demand gap (deficit) of about 3.1 million metric tons per annum (Falola et al., 2013). This problem has been linked to low farm productivity in the country (Daramola, 2013; Nkonya et al., 2010). However, this challenge can be overcome through investment in social capital among the farming population.

Social capital has been defined in different ways by different authors depending on the discipline and level of investigation. Burt (1992) defined social capital as friends, colleagues, and more general contacts through which one receives opportunities to use their financial and human capital. Ostrom (2000) viewed social capital as the shared knowledge, understanding, norms, rules and expectations about patterns of interactions that groups of individuals bring to a recurrent activity. Dekker and Uslaner (2001) looked at social capital as the value of social networks, bonding similar people and bridging between diverse people, with norms of reciprocity. Cohen and Prusak (2001) considered social capital as the stock of active connections among individuals-the trust, mutual understanding, and shared values and behaviours that bind the members of human networks and make possible cooperative action. To Dasgupta (2002), social capital is a system of interpersonal networks which enhances cooperation and collaboration that helps to create the economic opportunities. From the foregoing, this study considers social capital as the relationship between different social group members that determines how individual member can take advantage of whatever resources the group has.

Social relationships can play an important role in the daily lives of farming households, especially in Nigeria where these relationships can help bridge the numerous challenges facing self-sufficiency in rice production. This can in turn bring about efficient functioning of socioeconomic well-being, agricultural productivity, food security and economic performance of the agricultural sector. Thus, social capital has the potential to yield a stream of benefits that would make rice production more efficient, more innovative or simply expanded. Social relationships can create an avenue through which rice farmers can foster collective efforts towards their development to enhance development of their entreprises (Besette, 2004 and Mougeot, 2005). In view of this, this study examined social capital among rice farming households in Patigi and Edu Local Government Areas (LGAs) of Kwara State Nigeria. 
Specifically, the study:

(i) assessed the rate of participation of the farmers in social groups;

(ii) determine the productivity of rice farms in the study area;

(iii) examined how their participation influences productivity;

(iv) identified the benefits derived by the farmers from participating in social groups; and

(v) determined factors affecting participation of the farmers in social groups.

\section{MATERIALS AND METHODS}

The study was carried out in Patigi and Edu Local Government Areas (LGAs) of Kwara State, Nigeria. The two LGAs are the main rice producing areas of the state. The target population for this study was rice farming households in the study area. A two-stage random sampling procedure was employed to obtain the data. The first stage involved random selection of five farming communities from each LGA. The second stage involved a random selection of rice farming households from each of the selected communities based on the proportion of the rice farming households in each of the selected communities. A total of ninety farming households were used for the study. Information was sourced with the use of structured questionnaire administered to the household head and augmented with oral interview. Focus Group Discussion (FGD) approach was also used to supplement the findings obtained from the individual respondent.

Data collected were analyzed with descriptive statistics, four-point Likert scale, total factor productivity index, analysis of variance (ANOVA) and probit regression. Descriptive statistics such as frequency counts, percentage, mean and chart were used to examine the socio-economic characteristics of the respondents and to analyze the benefits derived from participating in social groups by the respondents. Fourpoint likert-type scale was also used to assess the level of participation in the groups by the respondents. This was rated from "low" (if the respondent participated in few meeting) to "very high" (if respondent participated in all meeting).

Total factor productivity (TFP) was used to evaluate farm productivity by the households. The choice of TFP, instead of single factor productivity (SFP), was because SFP ignores the role of other inputs in any observed output changes (Zepeda, 2001). The TFP index was measured as the ratio of total output quantity to the quantity of total input. Following Key and McBride (2005) and Ibrahim and Onuk (2010), is given as:

$$
\mathrm{TFP}=\frac{\mathrm{Y}}{\sum \mathrm{PiXi}}
$$

Where $\mathrm{Y}=$ Value of output $(\mathrm{N})$

$\mathrm{Pi}=$ unit price of ith variable input and $\mathrm{Xi}=$ quantity of ith variable input.

ANOVA was used to compare the productivity of the respondents based on their level of participation in social groups while the probit model was used to examine factors influencing participating in social groups by the respondents. The probit model is expressed as

$$
\operatorname{Prob}\left(Y_{i}=1 \mid X=\int_{-\infty}^{X^{\prime} \beta} \varphi(t) d t=\varphi\left(X^{\prime} \beta\right)\right.
$$

where $Y_{i}$ is an indicator variable equal to unity for respondents that participated, $\varphi($.$) is the standard normal$ distribution function, $\beta$ s are the parameters to be estimated and $X s$ are the determinants of the choice. $Y_{i}$ takes a value equal to 1 and 0 otherwise depending on whether respondent $j$ participates or not respectively. Emperically, the model can be represented as

$$
Y=\beta_{j} X_{i}+\varepsilon_{i}
$$

where $Y$ is the probability of a participating (equals 1 if a respondent participates and 0 if otherwise). $X_{i}$ are respondent's characteristics and $s_{i}$ is the error term. Based on relevant literature (Beard, 2005; Angba and Itari, 2012; Ekong, 2003; Sseguya et al., 2013; Weinberger and Jütting, 2001), the factors $\left(X_{i}\right)$ hypothesized to influence participation in social groups by the respondents are as follows:

$\mathrm{X}_{1}=\operatorname{Gender}($ male $=1$, female $=0)$

$X_{2}=$ Age (years)

$\mathrm{X}_{3}=$ Household size (number of household members)

$\mathrm{X}_{4}=$ Farm size (hectares)

$\mathrm{X}_{5}=$ Education (years of successful education)

$X_{6}=$ Opinion about influence of social group membership on religious fervency (positive $=1$, otherwise $=0)$.

$\mathrm{X}_{7}=$ Access to extension services $($ Access $=1$, otherwise $=0$ )

$\mathrm{X} 8=$ Income (Naira)

\section{RESULTS AND DISCUSSION}

\section{Socio-economic Characteristics of the Respondents}

Table 1 shows the socio-economic charactistics of the respondents. The majority (92\%) of them were male. Most of the household heads were married, suggesting that rice farming was a means of catering for the household by the farmers. This is also evident by the average household size of seven persons obtained in the study area. The age distribution of the respondents suggests that most of the farmers were relatively old.

Though the majority of the household heads had one form of formal education or the other, yet the results revealed that those who had tertiary education among them were few. This could be an indication of lack of interest in agriculture by university graduates in the study area. This is consistent with previous findings in the study area (Falola et al., 2013).

The farm size of many of the respondents ranged from four to six hectares while the average farm size was about four hectares. The majority $(53.3 \%)$ of the respondents earned less than N20,000 monthly (1USD $=\mathrm{N} 165)$. About $54.4 \%$ of the respondents had access to extension services while $45.6 \%$ did not. About $68.9 \%$ of the respondents opined that membership of social groups would have no adverse effect on their religious fervency while $31.1 \%$ thought otherwise.

\section{Social Group Participation Status of the Farmers}

Table 2 shows distribution of the respondents by membership of social groups. About $94.5 \%$ of the farmers were members of one social group or the other. However, the ones to which the farmers belong to most were farmers' group and religious associations. 
Table 1: Socio-economic Characteristics of the Respondents

\begin{tabular}{|c|c|c|c|}
\hline Characteristics & Category & No of Respondents & Percentage \\
\hline \multirow{2}{*}{ Gender } & Male & 83 & 92.2 \\
\hline & Female & 7 & 7.8 \\
\hline \multirow{4}{*}{ Marital status } & Single & 11 & 12.2 \\
\hline & Married & 71 & 78.9 \\
\hline & Divorced & 3 & 3.3 \\
\hline & Widowed & 5 & 5.6 \\
\hline \multirow{5}{*}{$\begin{array}{l}\text { Age (years) } \\
\text { Mean }=50 \text { years }\end{array}$} & $25-30$ & 3 & 3.3 \\
\hline & $31-40$ & 4 & 4.4 \\
\hline & $41-50$ & 17 & 18.9 \\
\hline & $51-60$ & 61 & 67.8 \\
\hline & Above 60 & 5 & 5.6 \\
\hline \multirow{4}{*}{$\begin{array}{l}\text { Household size (persons) } \\
\text { Mean = } 7 \text { persons }\end{array}$} & $1-5$ & 4 & 4.4 \\
\hline & $6-10$ & 35 & 38.9 \\
\hline & $11-15$ & 36 & 40.0 \\
\hline & $16-20$ & 15 & 16.7 \\
\hline \multirow{4}{*}{ Highest level of formal education attained } & No formal education & 39 & 43.3 \\
\hline & Primary education & 30 & 33.3 \\
\hline & Secondary education & 19 & 21.1 \\
\hline & Tertiary education & 2 & 2.2 \\
\hline \multirow{4}{*}{$\begin{array}{l}\text { Farm size (hectares) } \\
\text { Mean = } 4.2 \text { hectares }\end{array}$} & $1-3$ & 19 & 21.1 \\
\hline & $4-6$ & 44 & 48.8 \\
\hline & $7-9$ & 22 & 24.4 \\
\hline & $>9$ & 5 & 5.6 \\
\hline \multirow{5}{*}{$\begin{array}{l}{ }^{*} \text { Income (Naira/month) } \\
\text { Mean = N19,804.00 }\end{array}$} & $<20,000$ & 48 & 53.3 \\
\hline & $20,000-29,999$ & 17 & 18.9 \\
\hline & $30,000-39,999$ & 12 & 13.3 \\
\hline & $40,000-49,999$ & 9 & 10.0 \\
\hline & $>49,999$ & 4 & 4.4 \\
\hline \multirow[t]{2}{*}{ Access to extension services } & Have access & 49 & 54.4 \\
\hline & Do not have access & 41 & 45.6 \\
\hline \multirow{2}{*}{$\begin{array}{l}\text { Opinion about membership of social } \\
\text { group on religious fervency }\end{array}$} & Positive & 62 & 68.9 \\
\hline & Negative & 28 & 31.1 \\
\hline
\end{tabular}

Table 2: Distribution of Respondents by Membership of Social Groups ( $N=90)$

\begin{tabular}{|c|c|c|c|c|}
\hline \multicolumn{4}{|c|}{ Members of Social Groups $\left(n_{1}=85\right)$} & \multirow[b]{2}{*}{$\begin{array}{c}\text { Non-members of social } \\
\text { groups }\left(\mathrm{n}_{2}=5\right) \\
\left.\text { (Percentage }=\mathrm{n}_{2} / \mathrm{N} \times 100 \%\right)\end{array}$} \\
\hline Type of Group & $\begin{array}{l}{ }^{*} \text { No of } \\
\text { Respondents } \\
\text { (m) }\end{array}$ & $\begin{array}{c}\text { Percentage of } \\
\text { sub-group } \\
\left(\mathrm{m} / \mathrm{n}_{1} \times 100 \%\right)\end{array}$ & $\begin{array}{c}\text { Percentage of total } \\
\text { sample } \\
\text { (m/N X 100\%) }\end{array}$ & \\
\hline Cooperatives & 26 & 30.6 & 28.9 & \multirow{4}{*}{$5.5 \%$} \\
\hline Religious association & 47 & 55.3 & 52.2 & \\
\hline Mutual support group & 21 & 24.7 & 23.3 & \\
\hline Farmers' group & 52 & 61.2 & 57.8 & \\
\hline
\end{tabular}

Note: * Multiple responses allowed

The levels of participation of the farmers in the social groups are presented in Table 3. Those that, at least, highly participated in cooperatives, religious association, mutual support group and farmers' group accounted for about $73,94,81$ and $73 \%$ respectively. These results indicate a high level of participation of the rice farmers in social groups.

Table 3: Level of Participation in Social Groups by the Respondents

\begin{tabular}{|c|c|c|c|c|c|}
\hline \multirow{2}{*}{ Types of social groups } & \multicolumn{4}{|c|}{ Level of Participation } & \multirow{2}{*}{ Mean } \\
\hline & Low & Medium & High & Very high & \\
\hline Cooperatives $(n=26)$ & $3(11.5)$ & $4(15.4)$ & $6(23.1)$ & $13(50.0)$ & $3.11^{*}$ \\
\hline Religious association $(n=47)$ & $0(0.0)$ & $3(6.4)$ & $4(8.5)$ & $40(85.1)$ & $3.79^{*}$ \\
\hline Mutual support group $(n=21)$ & $1(4.8)$ & $3(14.3)$ & $17(81.0)$ & $0(0.0)$ & $2.76^{*}$ \\
\hline Farmers' group $(n=52)$ & $2(3.8)$ & $5(9.6)$ & $14(26.9)$ & $24(46.2)$ & $2.88^{*}$ \\
\hline
\end{tabular}

\section{Benefits Derived from Social Group Participation by} the Farmers

Figure 1 shows the benefits derived from participation in the social groups by the farmers. The figure shows that the major benefits derived from participating in the groups were credit facilities, support on econoomic activities, enhancement of agricultural production, access to market information and input support. 


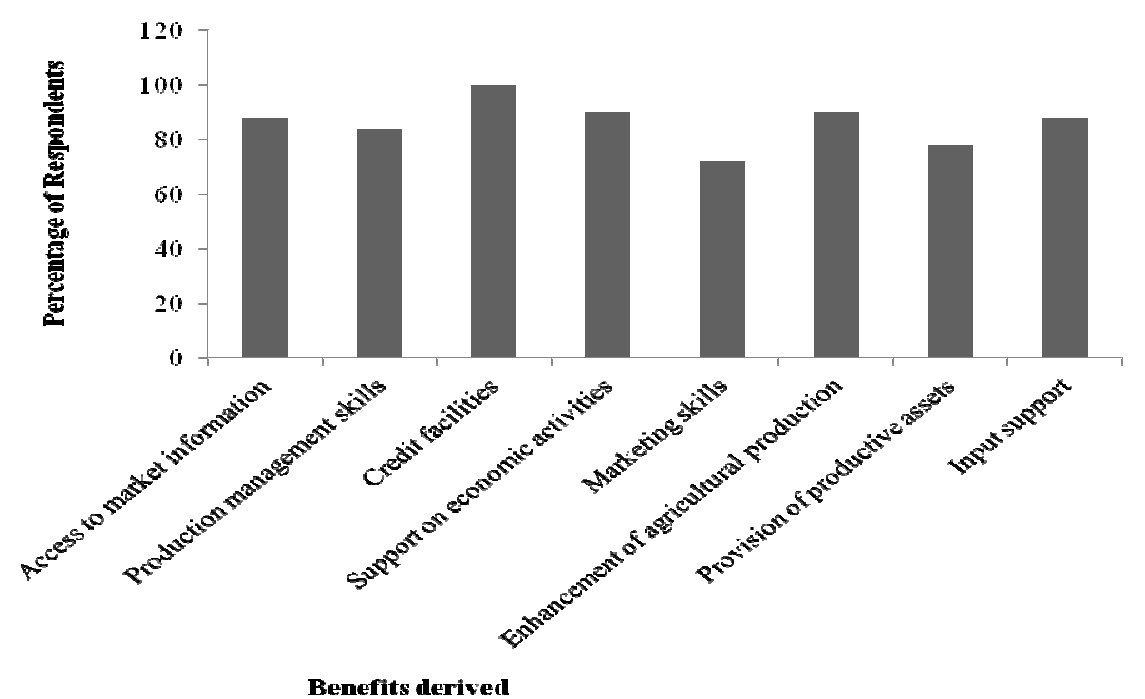

Figure 1: Distribution of respondents by benefits derived

Total Factor Productivity Estimates of Rice Farms in the Study Area

Table 4 shows the TFP indices of the rice farms in the study area. The TFP indices of the farms fall between $2.03-6.8$. Sixty percent of the farms fall between 3.1 5.0 TFP levels, while the average TFP is 4.2. This implies efficient resource-use by the rice farmers, such that their total farm output is, on the average, four times the total input used in farm production.

Table 4: Distribution of Respondents by TFP Indices

\begin{tabular}{lll}
\hline \multicolumn{1}{c}{ TFP indices } & $\begin{array}{c}\text { No of } \\
\text { Respondents }\end{array}$ & Percentage \\
\hline $2.1-3.0$ & 10 & 11.1 \\
$3.1-4.0$ & 25 & 27.8 \\
$4.1-5.0$ & 29 & 32.2 \\
$5.1-6.0$ & 9 & 10.0 \\
$6.1-7.0$ & 17 & 18.9 \\
\hline Minimum & $\mathbf{2 . 0 3}$ & \\
Maximum & $\mathbf{6 . 8}$ & \\
Mean & $\mathbf{4 . 2}$ & \\
Standard deviation & $\mathbf{1 . 0 5}$ & \\
\hline
\end{tabular}

Effects of Social Group on Farm Productivity of the Farmers

Table 5 shows the summary of ANOVA results on effects of participation of the farmers in social groups on their farm productivity. These results shows that the groups that had significant effects on farm productivity of the farmers were cooperatives $(P$-value $=0.009)$, mutual support group $(P$-value $=0.035)$ and farmers' association $(P$-value $=0.000)$. Investigations during the FGD revealed that most of the benefits derived by those who were members of social groups among the farmers were obtained from the three groups. This might be responsible for the significant effects of these groups.

Table 5: Effects of Participation in Social Groups on Farm Productivity of Respondents

\begin{tabular}{llll}
\hline Groups & F-value & p-value & Remarks \\
\hline Cooperatives & 11.158 & 0.009 & Significant \\
Religious association & 1.324 & 0.274 & Not significant \\
Mutual support group & 8.126 & 0.035 & Significant \\
Farmers group & 87.2 & 0.000 & Significant \\
\hline
\end{tabular}

\section{Determinants of Participation of the Farmers in Social Groups}

The results of the probit regression on factors influencing participation of the respondents in social groups are presented in Table 6 . The LR chi-square value was 103.28 , implying that the parameters included in the probit model were significantly different from zero at the $1 \%$ significant level. The value of the log likelihood was 20.9036 and was very highly significant $(P<0.000)$, indicating a strong explanatory power of the model.

Table 6: Probit Regression on Factors Influencing Participation in Social Group by Respondents

\begin{tabular}{|c|c|c|c|c|}
\hline \multicolumn{2}{|r|}{ Variable } & Estimated coefficient & Standard error & t-ratio \\
\hline \multicolumn{2}{|l|}{ Gender } & 0.0045 & 0.1243 & 0.0362 \\
\hline \multicolumn{2}{|l|}{ Age } & -0.8110 & 0.3961 & $-2.0475^{\star *}$ \\
\hline \multicolumn{2}{|c|}{ Household size } & 0.0097 & 0.3044 & 0.0319 \\
\hline \multicolumn{2}{|c|}{ Farm size } & 0.0107 & 0.3044 & 0.0352 \\
\hline \multicolumn{2}{|c|}{ Educational status } & 0.4565 & 0.2166 & $2.1076^{\star *}$ \\
\hline \multicolumn{2}{|c|}{$\begin{array}{l}\text { Opinion about influence of social group } \\
\text { membership on religious fervency }\end{array}$} & -0.0592 & 0.0183 & $-3.2350^{* * *}$ \\
\hline \multicolumn{2}{|c|}{ Access to extension services } & 0.9407 & 0.3380 & $2.7831^{* * *}$ \\
\hline \multicolumn{2}{|c|}{ Income } & 0.0342 & 0.5612 & 0.0609 \\
\hline \multicolumn{2}{|l|}{ Constant } & 2.3579 & 1.2989 & $1.8153^{*}$ \\
\hline LR chi2 (8) & $103.28^{* * *}$ & & & \\
\hline Prob > chi2 & 0.0000 & & & \\
\hline Pseudo R2 & 0.6817 & & & \\
\hline Log likehood & -20.9036 & & & \\
\hline
\end{tabular}


Olubunmi Abayomi et al.,

The significant variables that influenced participation of the respondents in social groups were age $(P<0.05)$, educational status $(P<0.05)$, opinion about influence of membership of social group on religious fervency $(P<0.01)$ and access to extension services $(P<0.01)$. Variables that positively influenced participation in social groups by the farmers were education and access to extension services while those that negatively affected their participation were age and opinion about influence of social group membership on religious fervency. The positive influence of education on participation in social groups by the farmers could result from the more potential capacity which educated individuals have. This helps to improve their social networks than their less educated colleagues (Imandoust, 2011; Mikiewicz et al., 2011). Also, access to extension services had a positive and significant influence on participation in social groups by the farmers. This could likely result from the fact that access to extension services can provide farmers with crucial information on the inherent benefits of social capital as a link to improve their agricultural productivity (Fakuda, 2007; Takemura et al., 2014).

The variables that had negative influences on participation in social groups by the farmers were opinion about influence of membership of social group on religious fervency and age. The negative relationship between perception of influence of membership on religious fervency and participation in social group by the farmers might result from the fact that 'religious people' are usually 'too' conscious of their membership in social groups. Consequently, this might negatively influence their participation in such groups. Meanwhile, the negative relationship between age and participation in social groups by the farmers could result from the higher level of innovativeness and socialization among young individuals than their older counterparts. Ceteris paribus, the older a farmer is, the less likely he will have interest in social networks (Falola, 2013; Muhammad-Lawal et al., 2009; Nwaru et al., 2010).

\section{CONCLUSION}

It can be inferred from this study that social capital plays a crucial role in productivity of rice farms in the study area. The study has also revealed that participation in social groups has the potential to yield a stream of benefits that would make rice production more encouraging, more economic or simply expanded. Moreover, the study reveals that the social groups that have significant effects on productivity of the farmers are mutual support group, cooperatives and farmers' group. Meanwhile, the study has shown that age, education, opinion about influence of social group membership on religious fervency and access to extension services are the significant factors that influence the farmers' participation in social groups.

Based on these findings, therefore, there is need for government to formulate relevant policies for better coordination of social groups so that rice farming households would be encouraged to participate in them. Such policies may include encouraging young and well educated individuals to actively participate in rice production. Besides, these group of farmers could form/join cooperative, mutual support group and farmers group, as this will improve their productivity. In addition, extension agents and other agricultural development stakeholders should overhaul their services in sensitizing
Sci. Technol. Arts Res. J., Jan-March 2015, 4(1): 215-220

and training the farmers on the importance of participating in social groups.

\section{Conflict of Interest}

All the authors declared no conflict of interest.

\section{REFERENCES}

Angba, A.O., Itari, P. (2012). Socio-economic factors influencing farmers' participation in community development organizations in Obubra Local Government Area of Cross River State, Nigeria. Canadian Social Science 8(1): 54-59.

Balogun, O.L., Adeoye, A., Yusuf, S.A., Akinlade, R.J., Carim-Sanni, A. (2012). Production Efficiency of Farmers under National Fadama II Project in Oyo State, Nigeria. International Journal of Agricultural Management and Development 2(1): 11-24.

Beard, V.A. (2005). Individual Determinants of Participation in Community Development in Indonesia. Government and Policy 23(1): 21-39.

Bessete, G. (2004). Involving the community: A guide to participatory development communication. IDRC. Publishers, pp.109 -110.

Burt, R. (1992). Structural holes, the social structure of competition. Cambridge, MA: Harvard University Press.

Cohen, D., Prusak, L. (2001). In good company, how social capital makes organizations work. Harvard Business School Press.

Daramola, A.G. (2013). The Nigerian agriculture and economic development: The way forward. A paper presented at the 27th Annual Conference of Farm Management Association of Nigeria (FAMAN) held between 26th - 30th August, 2013 at University of Ilorin, Nigeria.

Dasgupta, P. (2002). Economic progress and the idea of social capital. In P. Dasgupta and I. Serageldin (eds.), Social Capital: A Multifaced Perspective, World Bank, Washington DC.

Dekker, P., Uslaner, E.M. (2001). Introduction. In: Uslaner EM ed. Social capital and participation in everyday life. London: Routledge, pp. 1-8.

Ekong, E.E. (2003). Rural Sociology: An introduction and analysis of rural Nigeria. 2nd Edition. Dove Educational Publishers, Uyo.

Falola, A., Ayinde, O.E., Ojehomon, V.E.T. (2013). Economic analysis of rice production among the youths in Kwara State, Nigeria. Albanian Journal of Agricultural Sciences 12(3): 503-510.

Federal Ministry of Agriculture and Rural Development (FMARD) (2012). Agricultural Transformation Agenda: Repositioning agriculture to drive Nigeria's economy. Available online at http://www.emrc.be/ documents/document/20121205120841-agri2012special session-tony bello-min agric nigeria.pdf. Accessed on 25th June, 2013.

First Securities Discount House (FSDH) (2013). Nigeria economic outlook: 2013-2017. FSDH Research, 1-14. Available at http://www.fsdhsecurities.com /Profiles/Current/NIGERIA ECONOMIC OUTLOOK 201 3-2017.pdf. Retrieved on 18th December, 2013.

Fukuda, K. (2007). The direction of extension activities in formulating rural agriculture from the viewpoint of the needs of farmers: Based on the case of vegetable 


\section{Olubunmi Abayomi et alo,}

production areas in Yamagata prefecture and Chiba prefecture. Journal of Rural and Community Studies 105 25-40.

Idachaba, F.S. (2009). The looming food crisis. Newswatch, Lagos, (August 3), Special Colloquium Edition.

Imandoust, S.B. (2011). Relationship between education and social capital. International Journal of Humanities and Social Science 1(12): 52-57.

International Fund for Agricultural Development (IFAD) (2012). Enabling poor rural people to overcome poverty in Nigeria. Available at http://www.ifad.org/operations /projects/regions/pa/factsheets/ng.pdf. Retrieved on 18th December, 2014.

Mikiewicz, P., Jonasson, J.T., Gudmundsson, G., Blondal, K.S., Korczewska, D.M. (2011). Social capital and education: Comparative research between Poland and Iceland. (ed) Mikiewicz, P. Available at http://www.dsw.edu.pl/fileadmin/user upload/Upload/Soci al Capital and education. Comprarative research betw een Poland and Iceland.pdf. Retrieved April 27, 2014.

Muhammad-Lawal, A., Omotesho, O.A., Falola, A. (2009). Technical efficiency of youth participation in agriculture: $A$ case study of the Youth-in- Agriculture Programme in Ondo State, South Western Nigeria. Nigerian Journal of Agriculture, Food and Environment 5(1): 20-26.

Mougeot, J.A. (2005). The World of Local Organization (Agropolis). The social, political and environmental dimensions of urban agriculture. Earthscan and the International Development Research Centre (IDRC). ISBN: 1-84407-232-0.
Sci. Technol. Arts Res. J., Jan-March 2015, 4(1): 215-220

National Population Commission (NPC) (2012). The Nigeria population headcount reports. Accessed on 10/7/2012 from http://www.population.gov.ng/index.php?option= com content\&view=artide\&id=89

Nkonya, E., Pender, J., Kato, E., Omobowale, O., Phillip, D., Ehui, S. (2010). Enhancing agricultural productivity and profitability in Nigeria. International Food Policy Research Institute (IFPRI) Brief No. 19.

Ojo E. O., Adebayo P.F. (2012). Food security in Nigeria: An overview. European Journal of Sustainable Development 1(2):199-222.

Ostrom, E. (2000). Collective action and evolution of social norms. Journal of Economic Perspectives 14(3):137-158.

Sseguya, H., Mazur, R.E., Njuki, J.M., Owusu, F.Y. (2013). Determinants of participation and leadership in food security groups in Southeast Uganda: Implications for development programs and policies. Journal of Rural and Community Development 8(1), 77-97.

Takemura, K., Uchida, Y., Yoshikawa, S. (2014). Roles of extension officers to promote social capital in Japanese agricultural communities. PLOS ONE 9(3):e91975. doi:10.1371/journal.pone.0091975.

Weinberger, K., Jütting, J.P. (2001). Women's participation in local organizations: Conditions and Constraints. World Development 29(8): 1391-1404.

World Bank (2013). World Bank data. Available at http://data.worldbank.org/country/nigeria. Accessed 22nd November, 2013. 